\title{
Selective Deposition of Iron Oxides Thin Layers on Si(100) from Aqueous Solutions
}

\author{
Jong Hyeon Lee, Yeo Jin Song, Hỵe Jin Nam, and Duk-Young Jung

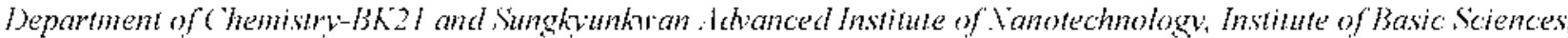

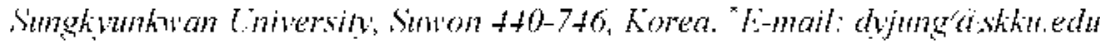 \\ Received Jantary 19, 2009, Accepted ipril 23, 2009
}

Key Worts: Iron oxides. Thin films. Chemical solution deposition. Microcontact printing

Chemical solution deposition (CSD) is used widely to deposil thin inorganic films on account of its simplicity and low cost. Morcover. this method can be casily scaled up. which is in contrast up other film deposition techniques. such as vacuum evaporation.' sputtering. ' spray py rolysis ${ }^{7}$ and chemical vapor deposition, ${ }^{1}$ Combined with micro-contact printing $(\mu \mathrm{CP})$ of OTS (ocladecy lirichlorosilanc). CSD has been applicd to micro patterning of a variety of inorganic thin films." where the OTS layers play a role of an organic resist 10 develop characteristic surface properties. In the ranges of selectiv ity obtained by various deposition techniques. CSD often produces thin film patterns with rather low selectivity and poor resolution because the OTS layers are influenced by the solution $\mathrm{pH}$ during deposition. This letter reports the development of micrometer scale patteming methods of $\alpha-\mathrm{Fe}_{2} \mathrm{O}_{3}$ (hematite) and $\beta$ FeOOH (akagancite) thin films using $\mu \mathrm{CP}$ and CSD. where the paticn resolution of thin films was enhanced using a buffer solution as the reaction media

$\mathrm{Si}(100)$ substrates were treated with a piranla solution for 10 min and washed with deionized water. acelone. and 2-propanol and dried with a stream of nitrogen. lron oxide thin filıns were deposited at $75^{\circ} \mathrm{C}$ on patterned OTS on $3 \times 3$ $\mathrm{cm}^{2}$ sized Si substrates in an aqucous solution. where the iron oxide precipitates are also formed during the deposition process. Stamps with a micron-size patterned relief stnucture were prepared by mixing polydimethylsiloxane (PDMS. Sylgard 184. Dow Corning) with a curing agent for 30 1 min. followed by

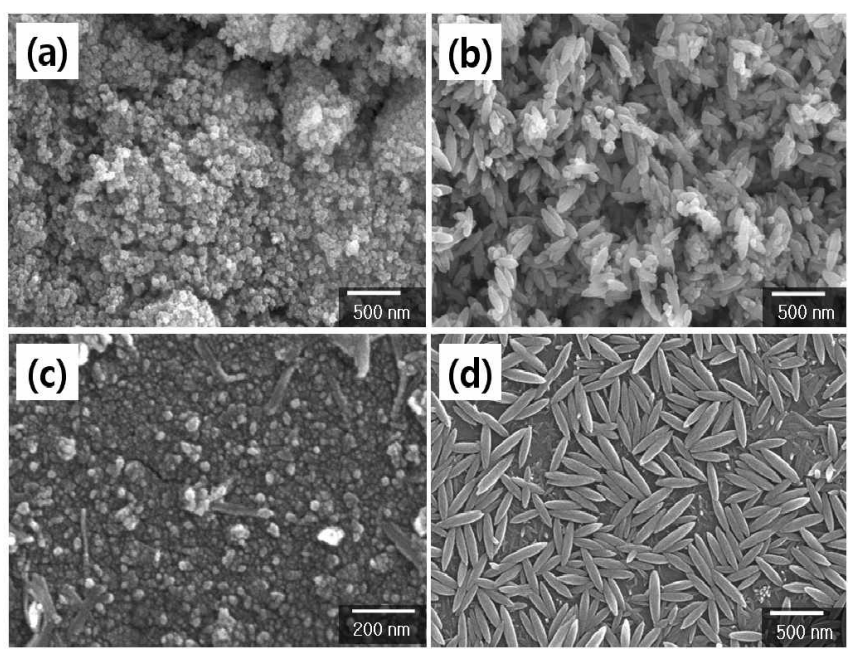

Figure 1. SI:M images of (a) hematite pou der, (b) akaganeite powder, (c) hematite thin film and (d) akagancilc thin lïm. curing at $80^{\circ} \mathrm{C}$ for $\mathrm{l} h$. A solution of OTS in anhydrous hexane ( $10 \mathrm{mM}$ ) was used as an "ink" and applied to the stamp using a spinner at $3000 \mathrm{rpm}$ for $30 \mathrm{~s}$. The inked stamp was placed in contact with $\mathrm{Si}$ and held in place for 30 seconds. yielding OTS thin films with approximatcly 30 A mass coverage. "1

$\mathrm{Fe}\left(\mathrm{NO}_{3}\right)_{3} \cdot 9 \mathrm{H}_{2} \mathrm{O}$ and $\mathrm{FeCl} l_{3} \cdot 6 \mathrm{H}_{2} \mathrm{O}$ were used as starting materials to produce hematite and akaganeite. respectively. The hematite thin films were deposited from a $0.05 \mathrm{M}$ iron nitrate solution. The akaganeite thin film was deposited from $0.05 \mathrm{M}$ iron chloride in $0.1 \mathrm{M}$ acctate buffer solution. The OTS-pattemed Si substrates were immersed in the solution for 2 h at 75 " $\mathrm{C}$ with constant stirring. The final $\mathrm{pH}$ range of the iron nitrate and iron chloride-acetate buffer solutions was $1.5 \sim 1.7$ and $2.5 \sim 3.0$. respectively: The color of the nitrate and chloride solutions was red-brown and light ochre. respectively. Bolh precipitates and thin films were claracterized by scaming electron microscopy (SEM) and X-ray diffraction (XRD). Figure $l(a)$ and (c) show SEM images of the precipitates and thin film prepared in $\mathrm{Fe}\left(\mathrm{NO}_{3}\right)_{\text {s }}$ solution. The deposited thin film was densely covered with hematite nanoparticles with spherical shapes with an average size of $20-50 \mathrm{~mm}$. XRD of both the pow der and film showed three predominant peaks at $33.2 .35 .6 .65 .4^{\circ} 20$. which were assigned to $(/ 0 f)$. $(/ / 0)$ and (2/f) for the hematite phase. ${ }^{\mid 1-13} \mathrm{~A} 1 \mathrm{pH}<2$. the formation of a hematite phase was more favorable than the other plases. such as goethite. ${ }^{1-1.15}$ Figure $1(\mathrm{~b})$ and (d) show spindle-like particles and thin films prepared in the $\mathrm{FeCl}_{3}$ solution. The powder sample was comprised of monodisperse $350 \mathrm{~nm}$ particles. and the thin films on Si contained a thin conformal laver of large particles. $500 \mathrm{~m}$ in sizc. overlying on the layer. The bottom laver also showed spindle-like particles. approximately 200 nim in size. imbedded on the layer deposited on Si. XRD of both tlic powder and film showed peaks for the akagancite phase corresponding to the $(200)$. $(400)$. $(600)$. ( 110$)$ and (310) planes. In the presence of $\mathrm{Cl}$. the fomation of the akagancite phase was more favorable than tle other phases. ${ }^{\text {If }}$

Figure 2(a) and (b) show area selective deposition of iron oxide thin films on OTS patterned Si. Figure 2(c) shows the surface profilometry scan of the pattemed iron oxide film. where the 500 un pattems show two separate hematite layers. 80 $\mu \mathrm{m}$ wide and $120 \mathrm{~mm}$ thick. The edges of the film are quite sharp. cren though the surface rougliness of the hematite laver is approximately $30 \mathrm{~nm}$. The chemical composition of the akagancite film was analyed by Auger eleciron spectroscopy at a $10 \mathrm{keV}$ beam vollage on a $15 \mu \mathrm{m} \times 15 \mu \mathrm{m}$ area after Ar ion sputtering for 10 scconds. In Figure 2(d). the akagancite covered 

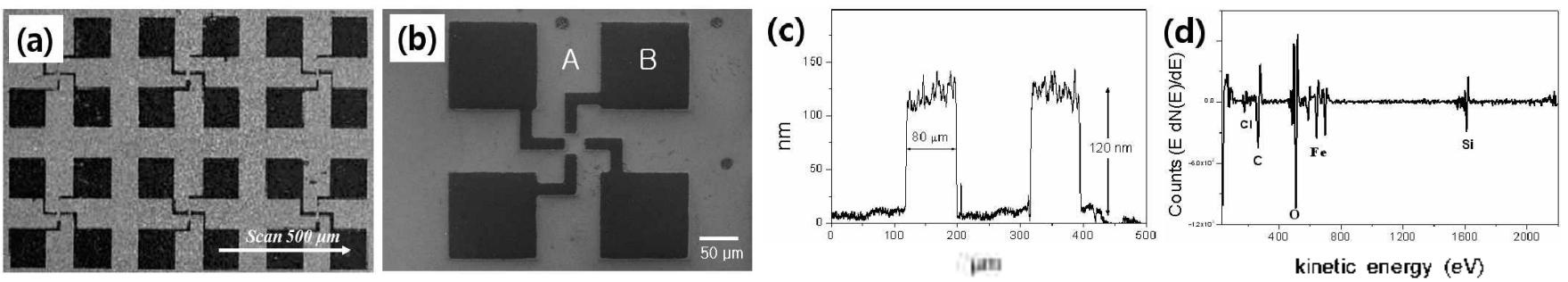

Figure 2. (a) Optical meroseopy image of patterned hematite thin 11lms, (b) SF:M image of akaganeste thin tilm, (c) Surtace protile of a selected area in tigute (ii), and (d) Auger electron spectra of areal (i) in tiggure (h)
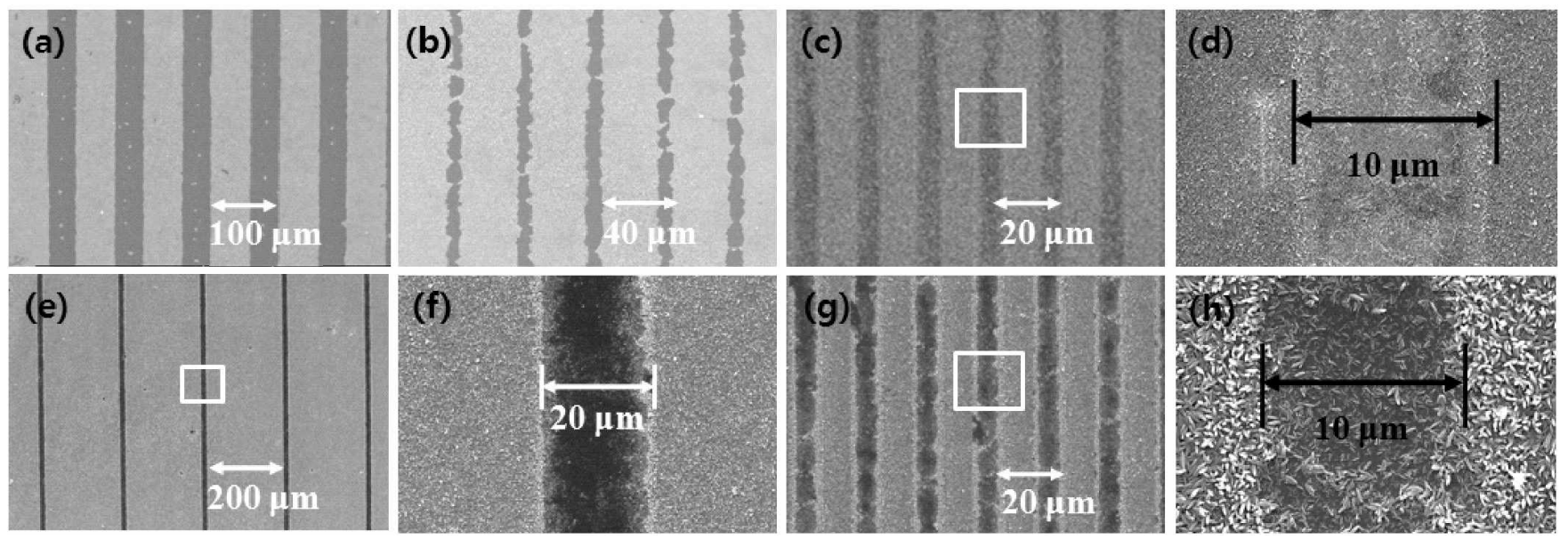

Figure 3. S]:M images of hemalite (a) (d) and akuganeite thin films (c) (h) with difierent printed ()IS lone widhs.

region (A) shows peaks for Fe. O. Cl. C and Si. while region (B) showed $\mathrm{Si}$ and $\mathrm{O}$ along with some $\mathrm{C}$ and Fe impurity. The peak for $\mathrm{Cl}$ from region (A) was assigned to $\mathrm{Cl}$ ions in the threc-dimensional tunnel of the akaganeite phase. ${ }^{1 \times 18}$ The strong peak for carbon in region (A) may be duc to the hydrocarbons of OTS. which shows that iron oxide thin films were deposited exclusively on the OTS printed area.

Figure 3 shows that the surface morphology and edge sharpness of the iron oxide films on the OTS printed Si depend strongly on the $\mathrm{pH}$ and starting materials. The bright regions in the SEM images are iron oxide films on the OTS printed arca and the dark ones are the Si surfaces. In the case of hematite shown in Figure 3(a) (d). the areas of the films are larger than that of the akaganeite films shown in Figure 3(c) (li). The size of the original OTS printed line patterns of the PDMS stamps shown in Figure 3 (b) was $20 \mu \mathrm{m}$ with a $20 \mu \mathrm{m}$ space. Howerer. the width of the hematite films was $30 \mu \mathrm{m}$ : the iron oxide films were exicnded approximately $5 \mu \mathrm{m}$ wide along both sides. In the case of the $10 \mu \mathrm{m}$ line and $10 \mu \mathrm{ml}$ space shown in Figure 3(c) and (d). the entire surface was covered with a hematitc lilms with no clear edges. In contrast. the akagancite films shown in Figure 3 (c) $\sim$ (h) werc approxintately $2 \mu \mathrm{m}$ wide along both sides of the lines. SEM also showed that the akagancite layers in the boundarics were thicker than that in the center. which was attributed to the diffusion of the OTS moiety during $\mu C \mathrm{P}^{1(1.19}$ In the $10 \mu \mathrm{m}$ OTS line with a 10 yun space shown in Figure 3 (h). the entire surface was covered with an akagancite laver but with clear boundaries. Therefore. the area selectivity of thin film deposition increases with increas- ing ionic strength in the buffer solution. Correlation between the edge-resolution of the films and the buffer strength of the starting solution will be discussed. In addition. the present synthetic method docs not require complicated multi-sicp modifications to perform $\mu \mathrm{CP}$ for iron oxide film pattenss. as reported earlier.

In conclusion. micrometer scale patterns of two types of iron oxide layers were obtained successfully using microcontact printing of OTS on Si. The iron oxide thin layers were formed on the OTS printed area. which was assigned to the cataly tic etching of OTS under the acidic experimental conditions. or to the heterogeneous nucleation on OTS lay cr. "2. It was also found that the high ionic strength of the reaction media helped increase the edge-resolution of the thin film patterns during pattenn formation. particularly at low $\mathrm{pH}$. Overall. this pattening method can be applied to other solution deposition processes.

\section{Experimental Section}

Materials and reiggents. The Sylgard $18+\mathrm{kit}$ was purchased from Dow Corning. The p-lype Si $(/ 00)$ wafers were oblained from Buy semi Co.. Korea. OTS (Octadeci ltrichlorosilane. 99\%). Ferric nitrate nonahy drate $\left(\mathrm{Fe}\left(\mathrm{NO}_{3}\right){ }_{2} \% \mathrm{H}_{2} \mathrm{O} .98 \%\right.$ ). Ferric chloride hexahydrate $\left(\mathrm{FeCl}_{2}-6 \mathrm{H}_{2} \mathrm{O} .98 \%\right)$. Sodium acetate buffer $(0.1$ M. $\mathrm{pH} 7.0$ ) and $n$-hexane (HPLC grade. 97\%) were purchased from Aldrich St.. Louis USA. All chemicals were of analy tical grade and oblained commercially:

Chanacterization. The iron oxide films were first assessed 
by optical microscopy. Selected samples from the optical microscopic inspection were studied by scanning electron microscopy (SEM. Phillips XL30FEG), surface profilometry (Tencor R-step 500), Auger electron spectroscopy (VG Scientific MicroLab $310-\mathrm{B}, 10 \mathrm{keV}$ ) at a $10 \mathrm{keV}$ beam voltage after $\mathrm{Ar}^{+}$ion sputtering for 10 seconds. X-ray diffraction (XRD) patterns were measured with a Rigaku X-ray diffractometer. D/MAX-2000 Ultima, on $\theta \sim 2 \theta$ scanning mode. The measurements were performed under the conditions of $40 \mathrm{kV} .30 \mathrm{~mA}$. and $\mathrm{Cu}-\mathrm{Ka}(\lambda=1.5405 \mathrm{~A})$. All XRD spectra of the films were calibrated using $\operatorname{Si}(200)$ peak from substrates $\left(2 \theta=32.9^{\circ}, d=\right.$ $2.7+\AA)$.

Acknowledgments. This work was supported by the Postdoctoral Research Program of Sungkỵunkwan University (2008).

\section{References}

1. Burton, L. C.; Hench, T. I. Appl. Phns. Lett. 1976, $29(9), 612$.

2. Yamaguchi, K.; Sato, S. Jph. Appl. Phvs. 1984, 23(1), 126.

3. Agnihotri, O. P. Gupta, B. K. Jpn. Appl. Phts. 1979, I8(2), 317.

4. Padam, G. K.; Malhotra, G. L.; Rao, S. U. M. J. Appl Phys. $1988,63,770$.
5. Jeon, N. L.: Clem, P.: Inng. D.-Y.: Lin, W.: Grolami, G. S.: Payne, D. A:; Nuzzo, R. N. Adv Mater: 1997, 9, 891.

6. Há, K.: Lee, Y. J.: Jung, D.-Y.: Lee, J. H.: Yoon, K. B. Adv. Mater 2000, $12(21), 1614$.

7. Hwang, Y. K.; Woo, S. Y.; Lee, T. H.; Jung, D.-Y; Kwon, Y. U. Chem. Water 2000, 12(7), 2059.

8. Lee, I. H.: Woo, S. Y.: Kwon, Y. U.: Jung, D.-Y. Bull Kor Chem. Soc. $2003,2 *(2), 183$

9. Kang, B.-C.; Lee, J. H.; Chae, H. Y.; Jung, D.-Y.; Boo, J. H. $J$. Iac. Sci. Technol. $B$ 2003, $21(4), 2740$.

10. Teon, N. L.; Finnie, K: Branshaw, K: Nuzzo, R. G. Langnuir $1997,13(13), 3382$.

11. Hematite (33-0664), akaganeite (34-1266), goethite (17-0536) in ICPDS cards; Intemational Center for Diffraction Data.

12. Grzeta, B.; Ristic, M.; Music, S. J. Allov Compd 2002, 334, 143.

13. Vasques-Mansiila, M; Zysler, R. D; Arciprete, C. J. Mlagn. Magn. Later: 1999, 204, 29.

14. Schwertmann, U.: Murad, E. Clon Clan Miner. 1975, 31(4), 33.

15. Atkinson, R. I.; Posner, A. M. J. Inorg Nitl Chem 1968, 30 , 2371

16. Cái, J.: Liu, J.; Gâ, Z.: Navrotsky, A.: Suib, S. L. Chem. Mater. 2001.13.4595.

17. Chambaere, D. G.: Grare, D. Phns Stat. Sol $1984,83,93$.

18. Conell, R. M.; Schwertmann. U. The Inn Oxides: VCH Publisher: New York, 1996.

19. Shin, H.; Jeon, J. U. J. Mater Res. 2001, 16(2), 564.

20. Masuda, Y. J. Cerantic Soc, Japan 2007, $115(2), 101$. 